\title{
PER1 wt Allele
}

National Cancer Institute

\section{Source}

National Cancer Institute. PER1 wt Allele. NCI Thesaurus. Code C97722.

Human PER1 wild-type allele is located in the vicinity of 17p13.1 and is approximately 16 $\mathrm{kb}$ in length. This allele, which encodes period circadian protein homolog 1 , plays a role in the maintenance of circadian rhythm. A chromosomal translocation t(12;17)(p13;p12p13) of this gene and the ETV6 gene was observed in a patient with acute myeloid leukemia evolving from a chronic myelomonocytic leukemia. 